\title{
【招待講演】
}

\author{
農業振興と地方大学の役割 \\ 一震災復興と福島大学農学系人材養成機能一 \\ 小山良太・今野聖士 \\ (福島大学・名寄市立大学)
}

\section{The Role of Regional University to Play in the Promotion of Agriculture}

\author{
Ryota KOYAMA (Fukushima University) \\ Masashi KONNO (Nayoro City University)
}

Key words; Recovery from Nuclear Disaster, Agriculture

はじめに

福島県は, 2011 年 3 月の東日本大震災及び原子 力発電所事故により，極めて甚大な被害を被った. 特に福島農業の被害は大きく, 長期的な課題とな っている.それは原子力災害による影響が大きい， 福島県は放射能污染対策, 帰村と営農再開, 風評 被害対策と新たな産地形成等という課題に值面し， 復興に向けた取り組みが 5 年経過した今もなお継 続している，これらは，震災・原発事故の影響で あると同時に, 今後さらなる少子・高齢化社会を 迎える日本農業が共通して抱える課題である。こ の意味で, 福島の農業の復興は, 将来の日本の農 業全体の振興につながると言ってもよい.

東北で唯一農学部を有しない福島県において, 福島大学に対し「農学系人材」の養成に関する要 請が相次いでいる. 福島大学では, ふくしま未来 食・農教育プログラムやうつくしまふくしま未来 支援センター農・環境復興支援部門による様々な 活動を行ってきたが，震災・原発事故の被害から
の農業の復興，さらには新たな時代の食産業の創 出のための人材育成や放射能対策を含めた知識・ 技能の習得を恒常的に行うことができる「農学系 人材の養成機能」はどうあるべきかを検討する必 要性を強く認識した。このため, 学内に「福島大 学農学系人材養成機能調査室」を設置し, 農学系 教育・研究機能のニーズ等の調査を行うとともに, 農学系人材養成機能の検討にあたっては，学内者 のみによるのではなく，地元自治体や農業関連団 体のご意見を踏まえる必要があるとの考えのもと， 「福島大学農学系人材養成機能のあり方に関する 協議会」及び「福島大学農学系人材養成機能のあ り方に関する検討会」を設置し，検討を重ねてき た. 2015 年 11 月には，調査室における現段階の 調査結果や，協議会及び検討会での議論を踏まえ， 協議会として福島大学における農学系人材養成機 能のあり方について一定の整理を行い,「福島大学 農学系人材養成機能のあり方に関する第一次報告 
書（平成 27 年 11 月)」としてとりまとめた。調 查室は 2016 年 3 月をもって調査実施の役割を終 え, 2016 年 4 月には, その機能を発展的に引き 継ぐ農学系教育研究組織設置準備室を設置してい る.

本稿では, 既存の農学系人材養成機関について 調査研究を行った結果を分析するとともに，新し い農学部の機能と役割について，また，農業振興 と地方大学の役割について, 現段階の特徴を明ら かにすることを課題とする.

\section{1. 東北地区における大学進学の現状}

東北地区（東北地方）における大学進学の状況 を, 文部科学省「学校基本調査」のデータを元に 概観していきたい. まず，表 1 に直近 3 年間の東 北・福島県における大学進学状況を示した。少子 化により 18 歳人口, 高校卒業者数は東北・福島県 ともに漸減している.また，大学進学率・短大進 学率は双方が 36〜39\%程度，5\%程度とほぼ同様 であるが，大きく異なるのが残留率である．短大 残留率は東北・福島県で差はないが大学の残留率 は東北 $33 \%$ 程度に対し，福島県は19\%台と 14 ポ イントもの差がある(2014). 表 2 で東北地区の県 別残留率を比較してみると，宮城が $56.9 \%$ と高い 一方で福島は $19.3 \%$ と東北の中でも自県に残る 大学生が少ないことがわかる，それでは，福島県 の高卒者はどこ一流出（進学）しているのであろ うか. 表 3 からその状況を見ると, 直近 3 年間は 同じ順位であり，1位は東京 $(21.3 \%) ， 2$ 位福島 (自県内進学・19.2\%)，3 位宮城（13.0\%）など となっている. その後は埼玉, 神奈川, 千葉と続 き, 首都圈への進学傾向が強いことが示唆される. 逆に福島県内一他県から進学する高卒者の状況を 整理したのが表 4 である. 福島県内大学への進学 者のうち $45.7 \%$ が県内の生徒であり, 他県からの

\begin{tabular}{|c|c|c|c|c|c|}
\hline 地域 & 作次 & 2013 & 2011 & 2015 & $\begin{array}{c}2015 \\
/ 2013 \\
\text { 比 }\end{array}$ \\
\hline \multirow{6}{*}{ 東北 } & 18武人口 & 96.127 & 91.096 & 89,965 & 0.94 \\
\hline & 商挍众業者数 & $86,38.3$ & 82.082 & 81,458 & 0.94 \\
\hline & 大学進学率 & $37.9 \%$ & $39.6 \%$ & $39.4 \%$ & 1.04 \\
\hline & 短大進学泽 & $5.2 \%$ & $5.2 \%$ & $5.4 \%$ & 1.04 \\
\hline & 大学残留率 & $33.7 \%$ & $33.6 \%$ & $34.1 \%$ & 1.01 \\
\hline & 短大残留得 & $66.3 \%$ & $65.4 \%$ & $66.5 \%$ & 1.00 \\
\hline \multirow{6}{*}{ 福自 } & 18藏人口 & 21,930 & 20.887 & 20,220 & 0.92 \\
\hline & 高校卒莱者数 & 19,067 & 18,103 & 17,847 & 0.94 \\
\hline & 大学進学率 & $37.2 \%$ & $36.1 \%$ & - & - \\
\hline & 知大進学率 & $5.6 \%$ & $5.3 \%$ & - & - \\
\hline & 大学残留率 & $19.0 \%$ & $19.3 \%$ & - & - \\
\hline & 智大残留莱 & $63.7 \%$ & $64.8 \%$ & - & - \\
\hline
\end{tabular}

料: 女部料学省学莫基本調查了各年放

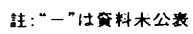

表2 2014年度 東北地区の大学残留率一筧表

\begin{tabular}{|c|c|c|c|c|c|c|}
\hline \multirow[b]{2}{*}{ 県名 } & \multicolumn{2}{|c|}{ 残留率 } & \multicolumn{2}{|c|}{ 大学 (人) } & \multicolumn{2}{|c|}{ 短期大学 (人) } \\
\hline & 大学 & $\begin{array}{l}\text { 短期 } \\
\text { 大学 } \\
\end{array}$ & $\begin{array}{l}\text { 自県内 } \\
\text { 進学 }\end{array}$ & $\begin{array}{c}\text { 進学者 } \\
\text { 全体 }\end{array}$ & $\begin{array}{c}\text { 自県内 } \\
\text { 倠学 }\end{array}$ & $\begin{array}{c}\text { 進学者 } \\
\text { 全体 }\end{array}$ \\
\hline 青森 & & 7 & 1794 & 5049 & 639 & 897 \\
\hline 岩手 & $27.3 \%$ & $57.5 \%$ & 1273 & 4662 & 414 & 720 \\
\hline 宮城 & $56.9 \%$ & $79.0 \%$ & 5800 & 10188 & 628 & 795 \\
\hline 秋日 & 23.1 & $51.3 \%$ & 00 & 3874 & 32 & 637 \\
\hline 山形 & $18.9 \%$ & $64.6 \%$ & 844 & 4456 & 403 & 624 \\
\hline 福島 & $19.3 \%$ & $64.8 \%$ & 1519 & 7870 & 704 & 1087 \\
\hline
\end{tabular}

資料: 文部科学省「学校基本調査」各年次

表3 福島県の大学進学者流出状況(上位10位)

\begin{tabular}{|c|c|c|c|c|}
\hline \multirow{2}{*}{ 順位 } & \multirow{2}{*}{ 進学先県名 } & \multicolumn{3}{|c|}{ 年別割合 } \\
\hline & & 2013 & 2014 & 2015 \\
\hline 1 & 東京 & $21.7 \%$ & $21.3 \%$ & $21.3 \%$ \\
\hline 2 & 福岛 & $19.0 \%$ & $19.3 \%$ & $19.2 \%$ \\
\hline 3 & 宮城 & $11.4 \%$ & $11.5 \%$ & $13.0 \%$ \\
\hline 4 & 埼玉 & $8.9 \%$ & $9.1 \%$ & $9.0 \%$ \\
\hline 5 & 神奈川 & $8.6 \%$ & $9.0 \%$ & $8.8 \%$ \\
\hline 6 & 千菓 & $6.7 \%$ & $6.3 \%$ & $6.0 \%$ \\
\hline 7 & 杤木 & $4.8 \%$ & $5.4 \%$ & $5.2 \%$ \\
\hline 8 & 茨城 & $3.6 \%$ & $3.7 \%$ & $3.5 \%$ \\
\hline 9 & 新潟 & $3.3 \%$ & $3.6 \%$ & $3.4 \%$ \\
\hline 10 & 山形 & $2.4 \%$ & $2.4 \%$ & $2.5 \%$ \\
\hline \multicolumn{2}{|c|}{ 東北地区から巢北地区外一の流出 } & $45.5 \%$ & $46.0 \%$ & $45.1 \%$ \\
\hline \multicolumn{2}{|c|}{ 福島県から福島県外一の流出 } & $81.0 \%$ & $80.7 \%$ & $80.8 \%$ \\
\hline
\end{tabular}

算料: 文部科学省「学校基本調查了各年次

流入は隣県である宮城・山形のほか, 北関東, 東 京などからの流入が多くなっている．また，近年 注目されているのが女子の進学動向である（表 5). 東北地区における女子 18 歳人口は漸減している が, 大学進学率は 1.2 倍, 7 ポイント近く上昇し 
ている. 福島県でも同様に 1.3 倍, 9 ポイント近 く上昇している. あわせて近県の農学系学部にお ける女子入学者の比率を見ると（表 6)，いずれも 40\%超が女子であり，女子の進学意向の向上，お よび農学系学部への興味関心の増加が示唆される.

\section{2. 近年における農学系学部（一部地域社会系等を}

\section{含む）改組・新設の状況}

近年, 農学系学部や地域社会系学部への改組・ 新設の動きが活発になっている. 短期的には文科 省が 2014 年 8 月に発表した「国立大学法人の組 織及び業務全般の見直しに関する視点」について (案)」の中で指摘された「特に教員養成系学部・ 大学院, 人文社会科学系学部・大学院については, 18 歳人口の減少や人材需要, 教育研究水準の確保, 国立大学としての役割等を踏まえた組織見直し計 画を策定し, 組織の廃止や社会的要請の高い分野 への転換に積極的に取り組むべきではないか.」と の文言を受けて，いわゆるゼロ免課程を中心とし た組織改編の動きがあるが，それ以前より，近年 高まってきた農学系学部人気や地域の課題にこた える学生を育てるための組織改編の動きがあり, その結果として図 1に示したような全国規模での 新設・改編が行われている. 全国で 35 年ぶりの農 学部新設となった龍谷大学や, 新潟県で 2 大学が 農学系学部を新設（予定）するなど，農学系を取 り巻く学部再編が活発になってきている.

\section{3. 福島大学における農学系人材食成に関する取り}

\section{組み}

このような農学系学部再編の気運の中, 福島県 においては長期的な対応が不可欠となる放射能被 害人の対応，また震災・放射能被害によって加速 する農業・農村・食を取り巻く厳しさに対応する ため, まさに今, 農学系の人材が必要とされてい
表4 福島県内大学への東北地区 進学者流入状況 (上位10位)

\begin{tabular}{|c|c|c|c|c|}
\hline \multirow{2}{*}{$\begin{array}{c}2015 \text { 年 } \\
\text { 順位 } \\
\end{array}$} & \multirow{2}{*}{$\begin{array}{c}\text { 進学元 } \\
\text { 県名 } \\
\end{array}$} & \multicolumn{3}{|c|}{ 年別割合 } \\
\hline & & 2013 & 2014 & 2015 \\
\hline 1 & 福島 & $46.3 \%$ & $47.2 \%$ & $45.7 \%$ \\
\hline 2 & 茨城 & $7.2 \%$ & $6.2 \%$ & $7.5 \%$ \\
\hline 3 & 宮城 & $7.5 \%$ & $7.4^{\circ} \mathrm{o}$ & $6.7 \%$ \\
\hline 4 & 杤木 & $6.3 \%$ & $7.1 \%$ & $6.4 \%$ \\
\hline 5 & 山形 & $6.2 \%$ & $5.1 \%$ & $5.4 \%$ \\
\hline 6 & 新潟 & $3.2 \%$ & $3.6 \%$ & $3.4 \%$ \\
\hline 7 & 岩手 & $3.1 \%$ & $3.5 \%$ & $3.3 \%$ \\
\hline 8 & 静岡 & 圈外 & $2.1 \%$ & $2.5 \%$ \\
\hline 9 & 東京 & $2.5 \%$ & 圈外 & $5.5 \%$ \\
\hline 10 & 群馬 & $2.4 \%$ & $2.1 \%$ & $2.4 \%$ \\
\hline$\frac{\text { 圏外 }}{\text { 果损 }}$ & 秋田 & $2.4 \%$ & $2.6 \%$ & 圈外 \\
\hline 東北地 & 外から流 & $21.2 \%$ & $22.5 \%$ & $22.8 \%$ \\
\hline
\end{tabular}

福島県内人

福島県外加流入 $\quad 53.7 \% \quad 52.8 \% \quad 54.3 \%$

资料: 文部科学省 $\lceil$ 学校基本調査 $」$ 各年次

\begin{tabular}{|c|c|c|c|c|c|}
\hline \multirow{2}{*}{ 地域 } & \multirow{2}{*}{ 項目 } & \multicolumn{3}{|c|}{ 年次別人口 (人) ·比率 } & \multirow{2}{*}{$\begin{array}{c}2015 \\
/ 2005 \\
\text { 代 }\end{array}$} \\
\hline & & 2005 & 2010 & 2015 & \\
\hline \multirow{4}{*}{ 東北 } & 女子 & & & & \\
\hline & 18歳人口 & 56,926 & 49,201 & 43,937 & 0.8 \\
\hline & $\begin{array}{c}\text { 大学 } \\
\text { 進学率 }\end{array}$ & $32.7 \%$ & $38.5 \%$ & $39.4 \%$ & 1.2 \\
\hline & $\begin{array}{c}\text { 地元大学 } \\
\text { 進学率 }\end{array}$ & $32.5 \%$ & $34.7 \%$ & $34.1 \%$ & 1.0 \\
\hline \multirow{2}{*}{ 福岛 } & $\begin{array}{c}\text { 女子 } \\
18 \text { 歳人口 }\end{array}$ & 13,132 & 11,343 & 9,977 & 0.8 \\
\hline & $\begin{array}{l}\text { 大学 } \\
\text { 進学率 }\end{array}$ & $26.4 \%$ & $32.4 \%$ & $35.0 \%$ & 1.3 \\
\hline
\end{tabular}

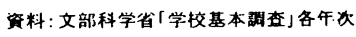

表6 2014年度 東北·北関東の主な農 学系国立大学における女子占有率

\begin{tabular}{cccc}
\hline 大学名 & 学部 & 入学者数女子占有率 \\
\hline 弘前 & 農学生命 & 188 & $41.0 \%$ \\
岩手 & 農 & 201 & $52.7 \%$ \\
東北 & 農 & 155 & $43.2 \%$ \\
山形 & 農 & 164 & $50.6 \%$ \\
茨城 & 農 & 120 & $46.7 \%$ \\
宇都宮 & 農 & 226 & $42.5 \%$ \\
新潟 & 農 & 165 & $50.9 \%$ \\
凟料:大学ホホートレートJWebサイト公表 \\
データによる \\
(http://portraits.niad.ac.jp)、 \\
2015/11/20閲覧
\end{tabular}




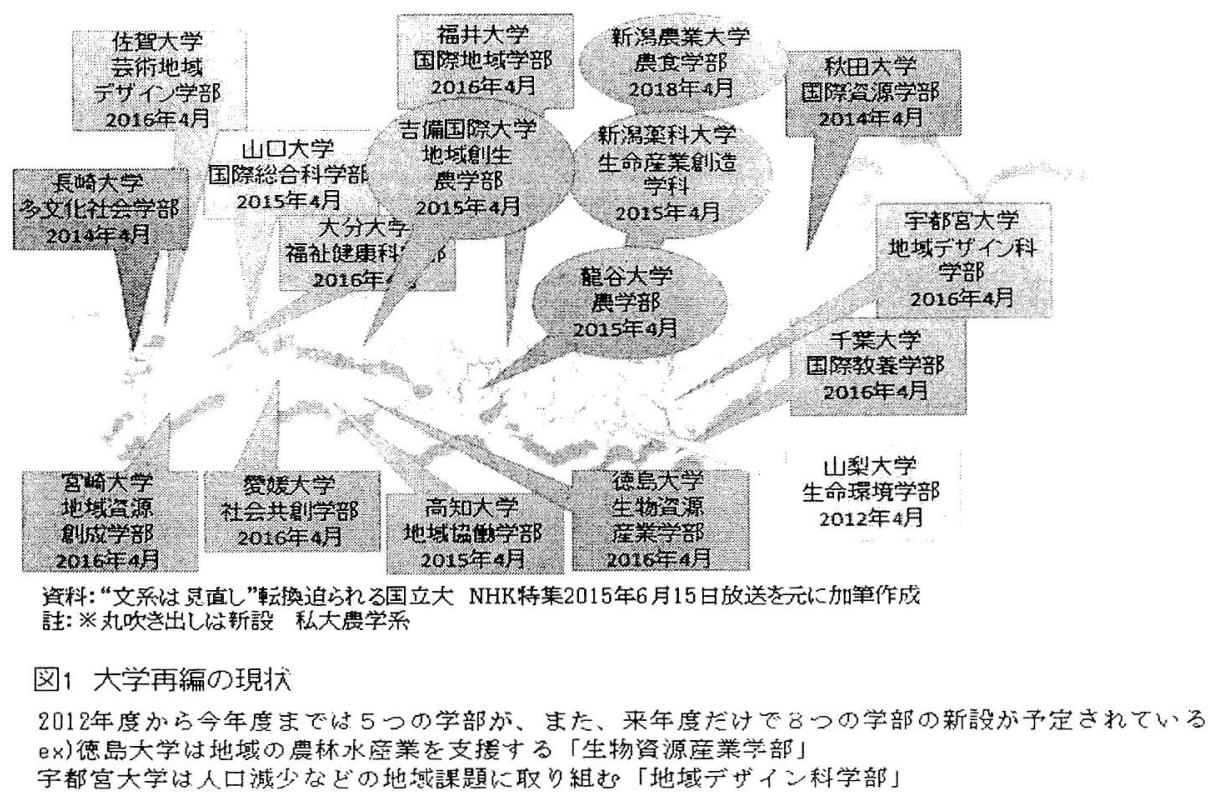

る. しかし, 福島県は東北で唯一農学系学部が存 在しない県であり，先の統計で明らかになった通 り, 新卒高校生の県内への残留状況はきわめて厳 しいのが現状である。このため, 福島大学では, 農学系の人材盖成を行う組織を何らかの形で設置 する事について調査・検討を行うこととした。 こ のためにまず, 福島大学農学系人材養成機能調査 室（以後調査室）を事務局総務課が空口となって 設置している. 以下では福島大学における設置検 討の課程と調査結果の概況について確認していく.

（1）福島大学農学系人材養成機能のあり方に関 する協議会及び検討会と全体の流れ

福島大学では, 農学系の人材養成組織の設置検 討を行うに当たって，学内だけではなく，県や農 業団体の方々の意見を頂戴する機会を設けるため, 二つの組織を設置した。 それが「福島大学農学系 人材養成機能のあり方に関する協議会」掞よび「福
島大学農学系人材養成機能のあり方に関する検討 会」(以下協議会, 検討会) である. 協議会は副学 長, 調查室長, 事務局長等学内構成員と, 県の部 長級・農業団体の常務等に参加いただいて構成し ている，検討会はより実質的な審議を行うため， 学内からは副学長, 調査室長, 各学類長, 事務局 長等，また県からは課長級，農業団体は部長級に ご参加いただいて構成している. 2015 年 5 月に初 回に合同会議を行った後, 検討会を5月と10月に 開催し随時行われた調査室の各調査結果の報告を 受ける形で, 検討会として「福島大学農学系人材 養成機能のあり方に関する第 1 次報告書 (案)」を 作成し，11月 6 日に開催された協議会にて同案が 一部修正の上，決定された。この結果を端的に述 ベれば,「新たに学士課程レベルの教育研究組織を 早期（早くて平成 30 年度を目途）に設置するこ とにより，農業分野においても教育・研究・社会 
貢献の役割を果たしていくことが福島大学の使命 と考える.」（同報告書のIV. まとめより引用）と なり，これを受け，福島大学学長が11月24日の 記者会見の席上にて, 学士レベルの農学系教育研 究組織を平成 30 年度 4 月を目途に設置すること決 定した。

\section{（2）福島大学農学系人材養成機能調査室におけ}

\section{る調査結果}

前掲報告書の根幹部分にあるのは，調査室にお いて実施された以下の 5 調査である. (1)本調査の 基本的な考え方及び調査内容, (2)高校進路指導者 向けアンケート調査結果, (3)福島県内の企業・団 体・自治体等向けアンケート調査結果, (4)先行大 学調查「龍谷大学, 徳島大学, 高知大学ヒアリン グ調査」結果，(5)農業高校ヒアリング調査結果, となっている.

\section{（3）本調査の基本的な考え万及び調査内容}

報告書では調査実施の目的を基本的な考え方と して以下のように示している.

福島大学は地域に開かれた大学として，農業が 従来から抱えてきた課題への対処とともに, 原発 災害の最前線にある高等教育機関として，その使 命と課題に対応した特色ある教育・研究拠点の拡 充を, 次により検討する. (1)県内に求められる農 学系教育・研究機能のニーズ調査, (2)県内の青少 年の農学系進学意向調査 (学校調査), (3)農林水産 業や食品産業など関連業界の就業調査, (4)国内の 教育・研究機関の調査等（新設校, 既存校）の 4 項目である。

2015 年度は, 高等学校における農学系の認知や 進学意向, 食品・農業生産・流通関連企業及び農 業生產法人などの就業動向, 地域振興・農村再生 に関わるコーディネート機能調査, 既存・新設大 学農学部における農学教育の実態などの基礎調査 を行う。これらを踏まえて, 福島の農業の復興・
産地再生に欠かせない人材養成に関わる組織体制， カリキュラム, 教育・研究施設, 福島県内外の連 携組織などを具体的に提示し，原子力災害を経験 した福島県における農学系人材養成組織の設置ビ ジョンを策定する.

以上の目的を踏まえ，調亘室では設置の前提と なる (主に県内の) ニーズ調査として，県内およ び福島大学に入学実績のある東北・関東の進路指 導担当教諭に対してアンケート調査を実施した (入口部分)。さらに, 県内の就職先として想定さ れる食品産業・流通業等の企業が農学系人材を需 要・また福島県に根ざした農学系の研究機関を必 要としているのかを確認するために調査を行った (出口部分).カリキュラムや実際の設置準備に関 する情報収集のためには，先行して農学系学部を 新設・改組している 3 大学に対してヒアリング調 查を行った，加えて，高大連携の希望・状況や農 学系の教育を行っている県内の農業高校に対して もヒアリング調査を実施した。

\section{4. 高校進路指導者向けアンケート調査結果}

発送対象は，県内の公立校及び私立校全校と， 福島大学に過去 5 年以内に 1 人以上の志願実績の ある東北・北関東地域の高校である，発送方法は 県内公立校については福島県教育委員会を通じた 配布，県内私立校及び県外校については郵送で実 施した。

総発送数は 443 通，回収率 $59.4 \%$ である．県内 公立校は $76.3 \%$ と高い回収率であった.

(1) 福島県内に農学系学部が設置された際の進 学意向について

「(1)10 名以上はいると思う」との回答は少ない ものの，「(2)数名程度はいると思う」及び「(3)1名 いるかどうかだと思う」の回答を合わせると約 $80 \%$ と高くなっており，設置された際の関心の高 
さが伺える.

（2）福島大学に農学部等が設置された際に進学 を薦めるか

本学農学部等の設置コンセブトが十分に決定さ れていない中, 全体で 47.3\%, 県内公立では $59.4 \%$ が進学を萀めると回答しており，期待の高さが伺 える.

（3）福島大学の農学部等で核とすべき分野につ いて

MT 比率 (その設問に対し何\%の人が YES と回答 したかがわかる) から見ると，「(4)食品に関わる学 問」の比率が 55〜 70\%と他よりも高くなっている. 次いで，県内私立を中心に比率が高い「(3)生命の 原理を探求する学問」や，県内校が $40 \%$ 強と高い 「(1)作物を育てるための学問」，僅差で「(5)経済・ 释営の観点から農業を支える学問」，「8動物に関

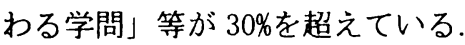

\section{（4）福島県に農学部等は必要か}

「(1)必要だと思う」との回答は全体で $62.7 \%$, 県内公立校は $66.2 \%$ ，同私立校は $77.8 \%$ と高く， 期待が寄せられている.「(2)どちらかというと必要 だと思う」との回答を合わせると，全体で $88.9 \%$ が必要性を感じている結果となった。 また,「(4)必 要ないと思う」との回答が全区分においてゼロと なっており，県内及び県外からもその設置に対す る期待の高さが伺える.

（5）自由記述欄について

158 件の意見が寄せられた。最も多くみられた のは福島大学における人材育成の方向性について (どのようなポリシーで人材育成を行うべきか， 高校や地域が望む人材育成像について）である. 地域で活躍できる人材の育成や総合科学としての 農学の教育として，地域経済やアグリビジネス， 育種や放射線対策といった複数の知識を有した人 材の青成を期待する声が奇せられた。
次に多く見られたのは，福島県（福島大学）に 設置する意義についてである，福島県に設置する ことにより，地域にとって有益な知識を持つ人材 が地域に供給されることを期待する意見や，隣県 に設置されている農学部ではなく福島県に設置す る意義を提案（放射線と植物・動物の関係，避難 等による地域へのダメージとその復興，海・山な ど豊富なフィールドを生かした教育等）する意見 が多く寄せられた。

そのほか，放射線・放射性物質に対寸る研究， 市民への情報提供を期待する意見, 総合科学とい う（仮の）コンセプトに対する賛成や反対が，主 に農業高校からは，学力試験だけではなく，志の 強い学生を受け入れる仕組みの整備に対する要望, 工学や商学など農学系ではない分野から安心して 志望できる，入学後のフォロー体制の整備を希望 する意見, 福島県農業短期大学校との役割の違い を明確にし, 福島で活躍する人材育成に継がる学 部であって欲しいとの期待などが寄せられた。

\section{5. 福島県内の企業・団体・自治体等向アンケート 調査結果}

発送対象は，県内の企業・団体（農協等の農業 団体，食品製造業者の協議会等) ・自治体とした. 県内 JA には単協（数市町村単位の農協）の他, 県 内の中央会, 全農（全国農業組合連合会）や共済 連（全国共済農業協同組合連合会）が含まれてい る. 市町村は被災地域も含めた県内全市町村を対 象とした。福島県食品産業協議会は全会員を対象 とし，福島県工業クラブ（主に大企業）は食品・ 医療系の業種を対象とした.生協 (生活協同組合) は購買事業を行っている5生協を対象とした。就 職先上位とは, 福島大学卒業生の就職先のうち, 直近 5 年間で 10 名以上の就職実績がある企業を対 象としている. 地域金融機関とは, 主に福島県に 
本部を置く金融機関である. 前述の就職先上位と 重なる部分が多いため同一カテゴリとした，福島 県ものづくり企業データベースとは, 県の商工労 働部商工総務課が管理している県内の製造業者の 基礎情報を集めたデータベースである．食料品・ 飲料で抽出した上で重複を除いた企業を対象とし ている．うつくしまふくしま農業法人協会は，農 業者の団体であり，全会員を対象とした。

回答については，おもに採用単位で回答するよ うに依頼している. (支社採用であれば支社の考え 方を，一括採用であれば本社の考え方を記述する ように依頼している.)

合計発送数は 353 通, 回収数は 168 通, 回収率 は $47.6 \%$ である．農業法人協会の回収率が $24.6 \%$ と低いものの, そのほかのカテゴリはおおむむ 40 〜60\%となっている.

\section{（1）業種・本社所在地・職員数について}

回答があった団体について，業種は「(5)食品製 造業」が最多の $35.6 \%$ であり, 次いで「(1市町村・ 県 (自治体)」,「(10)「その他（食品以外の製造業, 小売・卸売・物流)」となっている. また, 本社所 在地は，福島県が $89.9 \%$ と高くなっている.

（2）福島県に農学部等が必要とされているか, 及び尃門分野について

「(1)必要だと思う」との回答が 69\%であり，「(2) どちらかというと必要だと思う」との回答と合わ せると, 89\%が必要性を認めている.

農学部等が設置された場合にどの分野を重点的 に措置すべきかでは, JA と市町村, 就職先上位・ 地域金融機関は「(1)作物を育てるための学問」と 「(5)経済・経営の)観点から農業を支える学問」へ の期待が大きく, 食品産業協議会, 工業クラブ, ものづくり企業データベースは「(4)食品に関わる 学問」一の期待が大きく, 次いで「(1)作物を育て るための学問」と「(5)経済・経営の観点から農業
を支える学問」である. 生協は「(4)食品に関わる 学問」と「(6)地域・社会の観点から農業・農村を 支える学問」に対する期待が大きい，農業法人協 会は(1)（6に分散している．全体でみると「(1)作 物を育てるため0学問」が最多であり，次いで「(5) 経済・経営の観点から農業を支える学問」, 3 番目 が「(4)食品に関わる学問」となっている.

（3）採用意向・インターンシップ受け入れにつ いて

全体では「(1採用したい」が $52 \%$ と最多になっ ており，「(2)採用したいと思わない」との回答は $3 \%$ と少なくなっている.「(3)どちらとも言えない との回答も $45 \%$ と大きくなっているが，本学にお ける農学部等設置のプランニング, とりわけ養成 する人材像についての詳細がまだ検討段階であり， 十分に説明が出来ていないためであると考えられ る. 各カテゴリごとにみるとほぼ全体傾向と同様 であるが，農協に関しては 90\%以上が採用したい と回答しており，潜在的な需要が見込まれる.

福島大学に農学部等が設置された場合, 学生の インターシップ(就業体験・実施研修)の受け入れ についての意向では，カテゴリごとにばらつきは あるが、「(1)積極的に受け入れたい」および(2)受 け入れても良いとの回答が 30〜 50\%となってお り，一定数が受け入れを表明している.

\section{(4) 自由記述欄について}

52 件の意見が寄せられた。

最も多かったのは福島大学において具体的にど のような研究を行って欲しいかという意見・要望 である。

また，若者の県外流出を抑えるとともに，農業・ 農村・食品・流通などをより深く理解し，地域の ことを考え，地域と共に復興に向けて活動できる 人材を求めている. 


\section{6. 先行大学調査「龍谷大学・德島大学・高知大学 ヒアリング調査」結果'}

\section{(1) 龍谷大学}

(1)学部概要

龍谷大学農学部は, 2015 年 4 月に全国で 35 年 ぶりに新設された農学部である. 龍谷大学は仏教 系大学であり，校舎は滋賀県の瀬田キャンパス内 に置いている．新設に当たって校舎を新筑してい るが，3 学科が新校舎を，1学科（食料農業システ ム学科）が同じキャンパス内ながらやや離れた位 置にある旧国際学科校舎を利用している４つの 学科の学生定員（計 400 名）及び分野は，植物生 命科学科 (80 名, 植物生理·生化学·植物遺伝学),

資源生物科学科 (120 名, 植物育種学, 作物学), 食品栄養学科 (80 名, 管理栄養士養成), 食料農 業システム学科 (120 名, 農業経済学, 基礎会計・ 経営・社会学など）となっている．設置時の母体 となる学部等は無く，全くの新規設置である。こ のため，教員は全員を新規採用している(ただし， 各学部ごとに語学・教養ひ教員を一定数配置する ためその担当を除く)。学生の男女比は $7: 3 〜 6: 4$ （食品栄養学科 $1: 9 ）$, 教員数は 64 名である. 大 学院は設置検討中であり完成年度（初年度入学生 が卒業する年）までに設置を検討することとなっ ている. 入試体系が非常に細分化されているため, 平均的な倍率をみることは難しいが，最も募集人 数の多い一般入試〔A 日程〕の結果を見ると 2. 36 〜7.33 倍となっており，定員は十分に確保できて いると言える.

(2)各種ポリシー, カリキュラム等の特徴

龍谷大学農学部では, 仏教系大学という特徵か ら、「いのち」,「食の循環」という点を重視したカ リキュラム設計となっている. また, 自然科学領 域に軸足を置きつつ社会科学領域をも包攝した農 学教育を目指しており，それらを結びつけた教育
展開及び入試制度が取られている．具体的には， 農作物を基盤とした「食」の「生産」から「加土」 「流通」「消費」「再生」に至る一連の流れを「食 の循環」として捉え，その各段階を各学科が担い, そのなかで相互の交流・共通教育が図られるよう になっている.

入試制度は，全学科で理系入試と文采入試の両 方が実施されていることが特徵的である。植物生 命学科及び資源生物学科は理系の学問分野ながら 学生定員の $10 \%$ は文系科目による入試を, 食料農 業システム学科の $40 \%$ は文系科目による入試を 行っている. 食品栄養学科は化学の知識が必須の ため，理系入試のみである：このような入試制度 を採ることにより，高校時の履修スタイルによっ て基礎知識の差があるため, 講義の水準設定が難 しくなる.このため, 入学時にプレイスメントテ ストを義務づけ，下位 40 名は強制的に自身に不足 している生物や数学などの基礎知識 (高校レベル) のリメディアル教育（要卒単位外）を受けること となる.

学科間の交流と土・農業に対する共通基礎教育 を重視しており,全学生が農場実習を行っている.

農場は瀬田キャンパスから車で 10 分程度に位 置する農事組合法人からの借地である，学生は実 習時には 100 名ずつバスで向かうこととなり，ほ 場での作業のほか，地域の郷土学習なども行われ ている.

\section{(2) 徳島大学}

\section{(1) 学部概要}

徳島大学生物資源産業学部は, 2016 年 4 月に開 設される農学系学部である. 校舎は徳島市内の常 三島キャンパス内及び実習・研究用拠点用として 徳島県から無償貸与された石井町の徳島県農業大 学校跡地に新キャンパスを設置予定である. 設置 学科は生物資源産業学科（学生定員100名）の1 
学科であり，応用生命コース (同 35 名), 食料科 学コース (同 35 名), 生物生産システムコース (同 30 名) の 3 コースを設置予定である. 教員数は 45 名であり, 基本的に既存の学部からの人事異動に より配置されるが, 新規採用も6名ある. 大学院 は完成年度までの設置を検討している。

(2)各種ポリシー,カリキュラム等の特徵

徳島大学生物資源産業学部では, 養成する人材 像として,「1次産業, 食料, 生命科学に関する幅 広い専門知識と, 生物資源の製品化, 産業化に応 用できる知識と技術を有し，国際的視野に立って， 生物資源を活用した新たな産業の創出に貢献で きる人材を育成する」ことを掲げている．また， 教育の特徵として「最新の生命科学技術を応用し た生物資源の生産及び加工に加えて, 市場二ーズ に合致した製品化と起業化に必要な経営, 商品開 発等の基礎知識を総合的に学ぶ」としており, 生 物資源, 工学と経営, 流通といった多方面をつオ ローできる人材の育成を目指している.

各コースとも農学の一般的教養を重視しており， 学科共通となる科目が多く設定されている。 また ディプロマポリシーとして, 入学後の学修フォロ 一アップを重視しており, クラス担任が学修状況 をチェックする制度（「ラーニングポートフォリ オ」）を有している.

カリキュラムにおいて「現場」での経験を積ま せることを重視しており，3 ケ月以上のインター ンシップを必修としている。

入試制度については, 徳島県内の農業高校等と 連携した制度の構筑を検討中である。

徳島県の農業大学校跡地の無償貸与のほか, 役 職員の人事交流も行われるなど, 徳島県上の協力 体制を構築している.

\section{(3) 高知大学}

(1)学部概要
高知大学地域協働学部は, 2015 年. 4 月に開設さ れた農村等地域社会の発展をねらいとした学部で ある。校舎は高知市内の朝倉キャンパス内のプロ ジェクト研究棟を拠点としている. 基本的には学 内の既存資源の再編により設置されたものであり， 新たな校舎の設置等を行う予定は無い. 設置学科 は地域協働学科(学生定員60名)の1学科であり, コース設定等も無く60 名が同・のカリキュラム で学んでいる. 教員数は 24 名であり，既存の学部 等からの人事異動により配置されているが，新規 採用も 2 名ある. 初年度の入試倍率は 4.5 倍とな り，定員は十分に確保できているといえる.

(2)各種ポリシー，カリキュラムの特徴

高知大学地域協働学部では, 「地域力を学生の学 びと成長に活かし，学生力を地域の再生と発展に 活かす教育研究を推進することで,「地域活性化の 中核的拠点」としての役割を果たすことを目的」 として設置され，「高知県全域を中心的な教育研究 フィールドとし，地域との「協働」というアプロ 一チによって,地域とともに課題解決を図ること」 を目標としている，すなわち，単なる(一方的な) 支援・応援ではなく, 地域との協働という点に踏 み込んだ点が特徴である.

人材養成面では，「産業振興を担う「地域協働型 産業人材」を育成し, 地域社会の発展に貢献」し, 「特に，第一次産業，第二次産業，第三次産業の 協働により地域資源を活かした 6 次産業化を推進 してニュービジネスを創造できる」人材，具体的 に言えば,「「6 次産業化人」、「産業, 行政, 生活・ 文化の各分野における地域協働リーダー」を「地 域協働」の教育を通じて育成する」としている. ここでも「地域協㗢による教育」が重視されてい る. 具体的には, 県内 6 力所の実習先における実 習が 1 年生の 1 学期から半期で 30 コマ設定されて おり, 2 年次からは 60 コマに拡大される. 


\section{7. 農業高校ヒアリング調査結果}

福島県内の農業高校関係者に対し, 福島大学農 学系人材養成組織の設置に関してヒアリング調査 を実施するため，2015 年 8 月 10 日に福島県立明 成高等学校にて開催された「福島県高等学校長協 会農業部会および福島県高等学校教育研究会農業 部会第 2 回農場長会」において,「福島大学農学系 人材養成組織設置に関する愁談会」を実施した。

設置に対する期待は大きく, 100 年の悲願だとの 声も上がるほどであった。農業高校にとって，農 業高校から大学への進学ルートが開かれることは 大きなメリットであると考える．意欲の高い志願 者を安定的に確保するための高大接続の工夫が必 要である.

\section{（1）意見の概要}

○昨年度 18 名が大学へ進学しており, うち $1 / 3$ が農学系へ進学している. 県内に農学系学部がな いため県外の大学へ流出している. 福島県内に農 学系の学部があ机ば行きたいと考える生徒はいる. 今年は240名のうち 35 名ほど大学への進学希望が ある。

○農業系の教員養成が県内で出来ないので，農業 系の高校教員が不足している，是非養成できる力 リキュラムを作って欲しい. 農業高校の教員とし て母校一戻って来て欲しい.

○農家を志している生徒は農業大学校へ行く。こ のため農業高校の生徒は非農家からの入学が多く なってきており，就農等よりも進学意向が強くな ってきている。

○200名の在校生のうち15名が進学を希望してい る. そのうち 5 名が農学系を志望している. 他に も推薦等のルートがあれば, 進学したい生徒はい る. また県内の大学への進学を志望する生徒は一 定程度いると考えて良い.
○進学できる枠があるとなれば少なからず生徒の やる気につながる、農業高校を通じて農学部へ行 くというルートが出来ると農業高校としても大変 ありがたい。

○福島でしか出来ないこと, 今求められているこ ととして，植物工場などはわかりやすいのではな いか.

○食品科学や製造に関する学部や学科は人気が高 い. 私学以外で管理栄養士資格を取得できるとこ ろはあまりないので，もしそのようなカリキュラ ムがあれば，希望者は多くなると思われる.

○施設園芸と冬期のエネルギーコスト（地中熱な ど）といった低コスト技術開発が福島には必要だ と感じている.

○高校在学中に大学における教育に触れることが できる高校生向け公開講座等のプログラムを実施 してほしい.

\section{8. 調查結果のまとめ}

以上けように, 福島大学農学系人材養成機能調 査室において主に 4 つの調査を行ってきた.まず, 高校進路指導者向けアンケートにおいては, 福島 県内における学部レベルでの農学系人材養成機能 を持つ教育組織の必要性と, その学部レベルの組 織への進学意向が高いことが示された。

次に, 福島県内の企業等向けアンケートにおい ては, 農学系の人材養成機能を持つ組織の必要性 及びその卒業生の採用について一定程度以上の期 待があり，また，福島県内の農業問題に対応する ために必要と考える教育及び研究分野は，6次産 業化等による農家・農村の活性化, 食品を取り巻 く科学や産業といった既存け農学部では取り組み がやや遅れている分野を含め，多岐に扎たってい ることが示された。

先行大学の農学部調査では, 各大学 60 名, 100 
名, 400 名という学生定員が設定される中, 志願 倍率は 5 倍程度以上となっており，十分な社会的 ニーズを確認することができた（2015 年度）。ま た，学生教育については，養成すべき明確な人材 像を示したうえで，農学基礎教育とともに現場を 学ぶ実習の充実, リメディアル教育, 農業経営・ 農村振興などの地域課題に関する学習といった新 しい取り組みを中心に，充実した教育が行われて いることを確認することができた，また，特に国 立大学においては, 新たな農学系学部の運営のた めに自治体や関連団体との密接な連携が行われて いることも特記すべき事項である.

最後に, 農業高校へのヒアリング調査では, 農 業高校では農学系学部を志望する意欲旺盛な生徒 が毎年一定程度おり, 福島大学に農学系の学部が 設置されれば生徒の進学意欲がさらに増すこと, 現状では地元である福島県内で農業高校の教員養 成ができていないため, 福島大学における農業高 校の教員養成に期待していることが示された。

\section{おわりに}

日本の農学教育は, 専門分野の細分化により, 総合性, 関係性が分断される傾向がみられる. 東 日本大震災・原発事故を経験した福島では，放射 能污染という未知の課題に直面する中で, 農学に おける基礎分野である作物・栽培学, 土壤学, 農 業経営学を前提に, 研究対象となるフィールドを 共有し, 課題解決型の実践教育・実学的な研究を 推進する必要性があることを痛感した，福島大学 農学系人材養成機能のあり方に関する協議会にお いては, 地球レベルでの未知の課題を抱える福島 で求められる農学とは, 既存の農学部のあり方に とらわれず「総合科学としての農学」を再構筑す ることにあるとの共通認識が得られた。

「総合科学としての農学」を教育として展開する
ためには，専門分野を習得した上で，分野間の相 互の関連性を一体的に学ぶ仕掛けづくりが重要で ある．専門教育に関しては，食品科学（食品機能 開発学, 食品工学, 食品安全・衛生学, 発酵・醸 造学など), 作物・栽培学 (栽培学, 果樹, 野菜, 稲作, 有機農業, 農場利用など), 循環・環境学 (土 壤学, 生態学, 水利学, 農村計画, 森林環境など), 農業経営学 (農業経営学, 農業政策学, 農産物流 通・マーケティング, アグリビジネス, フードシ ステムなど）といった専門領域を体系的に学んだ 専門人材の養成を行い，その上で学際的な「総合 科学としての農学」を習得するようなプログラム の開発が求められる.

各専門分野が地域課題を共有し教育研究を推進 するためには，具体的なフィールドを想定するこ とが必要である。地域課題解決型のプロジェクト をベースとした実践的農学教育を行うことで「総 合科学としての農学」を修め, 農業を取り巻く広 範囲な場面で活躍できる農学系人材を盖成するこ とが求められている.

以上のように，震災・原子力災害への対応の中 でみえてきた地方大学に求められる農学系人材養 成機能は, 「課題解決型の実践的農学教育による食 料・農業・農村問題人主体的・革新的に対応でき る人材」を養成する機能である。この機能を果た すためには，「農」に加え「食」にも関連する分野 の教育を行える体制が必要である.

農学の射程に関しては,「生産農学からフードシ ステム農学へ」をコンセプトに, 農業・農村・農 業経営を対象とした生産過程の川上から, 加工・ 流通の川中および, 消費地 - 小売・食農教育も視 野に入れた川下までを一体的に学ぶ体系性の構筑 が求められる. 
注

1 先行大学調查「龍谷大学・徳島大学・高知大学 ヒアリング調査結果」及び「農業高校ヒアリング 調査結果」の内容は，ヒアリング結果やご恵与の あった資料をもとに，筆者の責任においてまとめ たものである.

引用・参考文献

[1]福島大学農学系人材養成機能のあり方に関する協 議会『福島大学農学系人材養成機能のあり方に関す る第 1 次報告書』2015 年 11 月.

[2]福島大学農学系人材養成機能のあり方に関する協 議会『福島大学農学系人材養成機能のあり方に関す る最終報告書』2016 年 6 月.

（付記）本稿の共著者の一人・今野は学会報告当時, 福島大学農学系人材養成機能調査室特任研究員として 調查実施及び報告書取りまとめを担当した。小山は同 室長を務めた。 